\title{
Carol Chase, Les Prologues du Lancelot-Graal dans le manuscrit BnF fr. 112
}

\section{Paola Cifarelli}

\section{(2) OpenEdition}

1 Journals

\section{Édition électronique}

URL : https://journals.openedition.org/studifrancesi/26026

DOI : $10.4000 /$ studifrancesi.26026

ISSN : 2421-5856

Éditeur

Rosenberg \& Sellier

\section{Édition imprimée}

Date de publication : 1 avril 2007

Pagination : 157

ISSN : 0039-2944

\section{Référence électronique}

Paola Cifarelli, « Carol Chase, Les Prologues du Lancelot-Graal dans le manuscrit BnF fr. 112 », Studi

Francesi [En ligne], 151 (LI | I) | 2007, mis en ligne le 30 novembre 2015, consulté le 23 novembre 2021. URL : http://journals.openedition.org/studifrancesi/26026 ; DOI : https://doi.org/10.4000/ studifrancesi.26026

Ce document a été généré automatiquement le 23 novembre 2021.

\section{(c) 9 (i) $\Theta$}

Studi Francesi è distribuita con Licenza Creative Commons Attribuzione - Non commerciale - Non opere derivate 4.0 Internazionale. 


\title{
Carol Chase, Les Prologues du Lancelot-Graal dans le manuscrit BnF
} fr. 112

\author{
Paola Cifarelli
}

\section{RÉFÉRENCE}

CAROL CHASE, Les Prologues du Lancelot-Graal dans le manuscrit BnF fr. 112, «Le Moyen Age»

CXI, fasc. 3-4, 2005, pp. 529-543.

1 Le manuscrit BnF fr. 112, bien connu des spécialistes des mises en prose arthuriennes, contient trois prologues sur lesquels l'A. focalise son attention. Comme C.C. le souligne à juste titre, ces textes posent plusieurs problèmes d'interprétation, tels l'attribution du roman à Robert de Boron ou le statut de la voix énonciatrice. Quant à la première de ces questions, le premier prologue semble suggérer qu'il n'y aurait pas contradiction entre cette attribution et celle, traditionnelle, de l'histoire de Lancelot à Gautier Map: «le compilateur pensait peut-être que Gautier Map aurait tiré certaines histoires d'un livre et les aurait écrites en latin, tandis que Robert les aurait traduites en français» (p. 537). En ce qui concerne l'instance énonciatrice, l'analyse du des deux premiers prologues se concentre sur les techniques utilisées par le compilateur-copiste pour s'approprier le texte. Enfin, l'A. examine les innovations introduites dans le dernier texte liminaire, surtout pour ce qui est de la tournure moraliste et le rôle compilateur. Cette étude est accompagnée de la transcription des trois textes en question. 